De Jure : Jurnal Hukum dan Syari'ah

Vol. 8, No. 2, 2016, h. 74-83

Print ISSN: 2085-1618, Online ISSN: 2528-1658

Available online at http://ejournal.uin-malang.ac.id/index.php/syariah

\title{
Keadilan Bagi Anak Luar Kawin Dalam Putusan Mahkamah Konstitusi Nomor 46/PUU-VIII/2010
}

\author{
Ahmad Farahi \\ Pengadilan Agama Nunukan \\ gemboze@gmail.com \\ Ramadhita \\ Fakultas Syariah UIN Maulana Malik Ibrahim Malang \\ ramadhita@syariah.uin-malang.ac.id
}

\begin{abstract}
Abstrak:
This article intents to examine the civil rights of children outside of married arising from Constitutional Court Decision No. 46 / PUU-VIII / 2010 review by justice aspects. This article is normative juridical research with a qualitative approach to the primary legal materials, namely Law No. 1 of 1974 on Marriage and the Constitutional Court Decision No. 46 / PUU-VIII / 2010. While the secondary legal materials such as books, journals, research related to children outside of married. Before the decision of the Constitutional Court No. 46 / PUU-VIII / 2010 was issued, children outside of marriage do not get the personal law rights, both the principles of Islamic justice and the West, as well as human rights perspective. After the emergence of Constitutional Court Decision No. 46 / PUU-VIII / 2010, children outside married have the same status as a legitimate child, with the requirement to have medical evidence.
\end{abstract}

Artikel ini bertujuan mengkaji hak-hak keperdataan anak luar kawin yang muncul akibat Putusan Mahkamah Konstitusi No. 46/PUU-VIII/2010 ditinjau dari aspek keadilan. Artikel ini merupkan hasil penelitian yuridis normatif dengan pendekatan kualitatif dengan bahan hukum primer yaitu Undang-Undang Nomor 1 Tahun 1974 tentang Perkawinan dan Putusan Mahkamah Konstitusi Nomor 46/PUU-VIII/2010. Sedangkan bahan hukum sekunder berupa buku, jurnal, penelitian terkait anak luar kawin. Sebelum putusan Putusan Mahkamah Konstitusi No. 46/PUU-VIII/2010 dikeluarkan, anak luar kawin tidak mendapatkan hak-hak keperdataannya secara adil. Baik menurut prinsip keadilan Islam, Barat, maupun perspektif HAM. Pasca munculnya Putusan Mahkamah Konstitusi No. 46/PUU-VIII/2010, anak luar kawin memiliki kedudukan yang sama dengan anak sah, dengan syarat memiliki bukti medis.

Kata Kunci: keadilan; anak luar kawin; keperdataan

\section{Pendahuluan}

Hak anak merupakan bagian dari hak asasi manusia yang harus dijunjung tinggi dan dilindingi oleh orang tua, masyarakat, dan negara. Berbagai fasilitas harus disediakan untuk menjamin pertumbuhan dan perkembangan anak secara optimal dan terarah. ${ }^{1}$ Pemenuhan hak-

\footnotetext{
${ }^{1}$ H. M. Hasballah Thaib and Iman Jauhari, Kapita Selekta Hukum Islam (Medan: Pustaka Bangsa Press, 2004$), 5$.
} 
hak tersebut dilaksanakan tanpa ada diskriminasi. ${ }^{2}$ Pasal 27 ayat (1) UUD 1945 menghendaki seluruh warga negara bersamaan kedudukannya dalam hukum. Konvensi Hak Anak (Convention on the Rights of Child) juga menghendaki bahwa setiap anak harus dihormati dan dijamin hak-haknya tanpa diskriminasi dalam bentuk apapun tanpa dipandang ras, warna kulit, jenis kelamin, bahasa, agama, keyakinan, bangsa, etnik, kekayaan, kelahiran atau kedudukan lain dari anak atau orang tua anak atau pengasuh yang sah, maka hak-hak anak luar kawin juga dijamin tanpa ada diskriminasi. ${ }^{3}$

Meskipun demikian, dalam Undang-Undang Nomor 1 Tahun 1974 tentang Perkawinan masih membedakan hak-hak anak berdasarkan status perkawinan orang tuanya. ${ }^{4}$ Bagi anakanak yang dilahirkan dalam perkawinan yang sah mempunyai hubungan perdata dengan ayah dan ibunya. Sedangkan anak-anak yang dilahirkan di luar perkawinan hanya memiliki hubungan keperdataan dengan ibu dan keluarga ibunya saja. ${ }^{5}$ Tidak adanya peraturan pemerintah yang mengatur anak luar kawin sebagaimana diperintahkan Undang-Undang Perkawinan mengindikasikan pemerintah belum serius dalam menangani persoalan ini. Meskipun anak-anak yang terlahir di luar perkawinan yang sah telah menanggung beban mental bahkan diskriminasi pada aspek keperdataan. Akte kelahiran anak luar kawin tidak memuat informasi yang lengkap. Nama ayah tidak dicantumkan sehingga akan berdampak secara sosial dan psikologis bagi si anak dan ibunya. Ketidakjelasan status ini, menyebabkan hubungan antara ayah dan anak tidak kuat dan ayah si anak dapat menyangkal keberadaannya. ${ }^{6}$

Pembahasan hak anak luar kawin kembali menjadi sorotan setelah Mahkamah Konstitusi mengeluarkan Putusan Nomor 46/PUU-VIII/2010 yang dalam amar putusannya menegaskan bahwa Pasal 43 ayat (2) bertentangan dengan UUD 1945 secara bersyarat (conditionally unconstitutional). Putusan ini menyatakan bahwa anak yang dilahirkan di luar perkawinan mempunyai hubungan perdata dengan ibunya dan keluarga ibunya serta dengan laki-laki sebagai ayahnya yang dapat dibuktikan berdasarkan ilmu pengetahuan dan teknologi dan/atau alat bukti lain menurut hukum mempunyai hubungan darah, termasuk hubungan perdata dengan keluarga ayahnya. ${ }^{7}$ Putusan ini menimbulkan kontroversi di masyarakat. Putusan ini dianggap melegalkan perzinaan. Majelis Ulama Indonesia (MUI) misalnya, merespon putusan ini dengan mengeluarkan fatwa mengenai kedudukan anak zina. ${ }^{8}$ Sementara itu, Moh. Mahfud MD $^{9}$ menegaskan bahwa putusan Mahkamah Konstitusi tentang anak luar nikah hanya fokus pada masalah keperdataan antara anak luar nikah dengan ayah biologis. Amar putusan Mahkamah Konstitusi, menurut Mahfud, tak berbicara tentang hubungan silsilah keturunan (nasab). ${ }^{10}$

M. Akil Mochtar ${ }^{11}$ menambahkan bahwa putusan Mahkamah Konstitusi dibuat semata untuk memberikan perlindungan keperdataan anak luar nikah atas ayah biologisnya, walaupun keabsahan perkawinannya masih dipersoalkan. Penerapan putusan Mahkamah Konstitusi harus dilakukan secara cermat oleh lembaga peradilan, baik peradilan umum maupun peradilan agama, dalam menilai ada tidaknya hubungan darah dan hubungan hukum antara ayah dan anak luar nikah. Undang-Undang Perkawinan dan juga putusan Mahkamah Konstitusi, hanya

\footnotetext{
2 Andi Syamsu Alam and M Fauzan, Hukum pengangkatan anak perspektif Islam (Rawamangun, Jakarta, Indonesia: Kencana Prenada Media Group, 2008), 1.

${ }^{3}$ Pasal 1 Konvensi Hak Anak PBB

${ }^{4}$ Undang-Undang Nomor 1 Tahun 1974 tentang Perkawinan

${ }^{5}$ J Satrio, Hukum keluarga tentang kedudukan anak dalam undang-undang (Bandung: Citra Aditya Bakti, 2000), 5.

${ }^{6}$ M. Idris Ramulyo, Perbandingan Pelaksanaan Hukum Kewarisan Islam dengan Kewarisan Menurut Hukum Perdata (BW) (Jakarta: Sinar Grafika, 1994), 5.

${ }^{7}$ Putusan Mahkamah Konstitusi Nomor 46/PUU-VIII/2010

8 "Putusan MK Tak Bermanfaat Untuk Anak Luar Kawin," accessed November 29, 2012, http://www.hukumonline.com/berita/baca/lt4f7475cd1eb4d/putusan-mk-tak-bermanfaat-untuk-anak-luar-kawin.

${ }^{9}$ Ketua majelis hakim dalam putusan Putusan Mahkamah Konstitusi Nomor 46/PUU-VIII/2010

${ }^{10}$ Ariyanto, Mahfud MD, Hakim Mbeling (Jakarta: Konstitusi Press, 2013), 133.

${ }^{11}$ Salah satu hakim anggota dalam Putusan Mahkamah Konstitusi Nomor 46/PUU-VIII/2010
} 
merupakan aturan hukum yang bersifat umum (lex generalis) dalam mengatur status dan kedudukan anak. Sementara itu, ada aturan lain yang sifatnya lebih khusus (lex specialis) seperti KUHPerdata dan Undang-Undang Peradilan Agama yang dilengkapi dengan Kompilasi Hukum Islam. Perlindungan terhadap anak diluar perkawinan harus dilaksanakan secara proporsional yakni dikembalikan kepada peraturan peraturan perundang-undangan yang berlaku dan adat istiadat setempat dengan tidak menafikan hukum agama yang bersangkutan. ${ }^{12}$ Penjelasan anggota majelis hakim Mahkamah Konstitusi di atas belum memberikan kejelasan tentang status dan hak keperdataan anak luar kawin. Artikel ini berupaya mengkaji hak keperdataan anak luar kawin dalam putusan Mahkamah Konstitusi Nomor 46/PUU-VIII/2010 yang ditinjau dengan prinsip keadilan.

\section{Metode Penelitian}

Penelitian ini termasuk katagori penelitian yuridis normatif karena berupaya mengkaji secara mendalam tentang hak keperdataan anak luar kawin dalam Putusan Mahkamah Konstitusi Nomor 46/PUU-VIII/2010. ${ }^{13}$ Adapun pendekatan yang digunakan adalah pendekatan kualitatif karena penelitian ini menghasilkan data yang bersifat deskriptif tentang hak keperdataan abak luar kawin sebelum dan sesudah Putusan Mahkamah Konstitusi Nomor 46/PUU-VIII/2010. ${ }^{14}$ Bahan hukum ${ }^{15}$ yang digunakan dalam penelitian hukum ini berupa bahan primer yaitu Undang-Undang Nomor 1 Tahun 1974 tentang Perkawinan dan Putusan Mahkamah Konstitusi Nomor 46/PUU-VIII/2010 dan bahan hukum sekunder yaitu buku, tesis, jurnal dan dokumen-dokumen yang mengulas tentang prinsip keadilan dan juga putusan Mahkamah Konstitusi Nomor 46/PUU-VIII/2010 yang nantinya akan dijadikan sebagai analisis dalam penelitian ini. Selain itu digunakan pula kamus hukum ensiklopedia sebagai bahan hukum tersier. ${ }^{16}$

\section{Hasil dan Pembahasan \\ Kedudukan Anak Luar Kawin Perspektif Hak Asasi Manusia}

Perlakuan diskriminatif terhadap hak-hak keperdataan anak luar kawin tidak selaras dengan prinsip konsep Hak Asasi Manusia. Pasal 1 Deklarasi Universal Hak Asasi Manusia (DUHAM), disebutkan bahwa semua orang dilahirkan merdeka dan mempunyai martabat dan hak-hak yang sama. Mereka dikaruniai akal dan hati nurani dan hendaknya bergaul satu dengan lain dalam persaudaraan. ${ }^{17}$ Pasal 2 berbunyi bahwa setiap orang berhak atas semua hak dan kebebasan-kebebasan yang tercantum di dalam Deklarasi ini dengan tidak ada pengecualian apa pun, seperti pembedaan ras, warna kulit, jenis kelamin, bahasa, agama, politik atau pandangan lain, asal-usul kebangsaan atau kemasyarakatan, hak milik, kelahiran ataupun kedudukan lain. ${ }^{18}$ Secara spesifik Pasal 25 ayat (2) DUHAM menyatakan bahwa ibu dan anakanak berhak mendapatkan perhatian dan bantuan khusus. Semua anak, baik yang dilahirkan di dalam maupun di luar perkawinan, harus menikmati perlindungan sosial yang sama. ${ }^{19}$ Deklarasi Hak Anak juga menghendaki bahwa anak hendaknya menikmati semua hak-hanya, tanpa diskriminasi karena alasan ras, warna kulit, jenis kelamin, bahasa, agama, pandangan politik

\footnotetext{
12 Irma Devita, "Pengertian Anak Luar Kawin Dalam Putusan MK," accessed October 28, 2014, http://irmadevita.com/2013/pengertian-anak-luar-kawin-dalam-putusan-mk/.

13 Soerjono Soekanto and Sri Mamudji, Penelitian Hukum Normatif: Suatu Tinjauan Singkat (Jakarta: RajaGrafindo Persada, 2006), 23.

${ }^{14}$ Burhan Ashshofa, Metode Penelitian Hukum (Jakarta: Rineka Cipta, 2001), 16.

${ }^{15}$ Peter Mahmud Marzuki, Penelitian Hukum (Jakarta: Kencana, 2010), 141.

16 Johnny Ibrahim, Teori Dan Metode Penelitian Hukum Normatif (Malang: Bayu Media Publishing, 2006), 296.

${ }^{17}$ Pasal 1 Deklarasi Universal Hak Asasi Manusia PBB

${ }^{18}$ Pasal 2 Deklarasi Universal Hak Asasi Manusia PBB

${ }^{19}$ Nasir Djamil, Anak Bukan untuk Dihukum: Catatan Pembahasan UU Sistem Peradilan Anak (Jakarta: Sinar Grafika, 2013), 26.
} 
atau pandangan lainnya, asal-usul kebangsaan atau sosial, kekayaan, kelahiran, atau status sosial lainnya, baik dirinya maupun keluarganya; Setiap anak juga harus dilindungi dari setiap praktek diskriminasi berdasarkan rasial, agama, dan bentuk-bentuk lainnya. ${ }^{20}$

Dalam UUD RI Tahun 1945, hak asasi anak diatur dalam 28 B ayat (2) yang menyatakan bahwa setiap anak berhak atas kelangsungan hidup, tumbuh dan berkembang, serta memperoleh perlindungan dari kekerasan dan diskriminasi. Peraturan serupa ditemukan dalam UndangUndang No. 39 Tahun 1999 Tentang Hak Asasi Manusia. Pasal 2 yang berbunyi bahwa Negara Republik Indonesia mengakui dan menjunjung tinggi hak asasi manusia dan kebebasan dasar manusia sebagai hak yang secara kodrati melekat pada dan tidak terpisahkan dari manusia, yang harus dilindungi, dihormati, dan ditegakkan demi peningkatan martabat kemanusiaan, kesejahteraan, kebahagiaan, dan kecerdasan serta keadilan. ${ }^{21}$ Juga pada Pasal 3 ayat (2) Setiap orang berhak atas pengakuan, jaminan, perlindungan dan perlakuan hukum yang adil serta mendapat kepastian hukum dan perlakuan yang sama di depan hukum. ${ }^{22}$ Dalam UndangUndang 23 Tahun 2002 sebagaimana telah diubah dengan Undang-Undang 35 Tahun 2004 tentang Perlindungan Anak menyatakan bahwa Setiap orang dilarang memperlakukan anak secara diskriminatif yang mengakibatkan anak mengalami kerugian, baik materiil maupun moril sehingga menghambat fungsi sosialnya. Negara, masyarakat, dan orang tua memiliki kewajiban mengupayakan perlindungan terhadap anak agar proses tumbuh-kembangnya tidak terganggu. ${ }^{23}$ Tidak adanya pemisahan antara anak yang sah dan anak luar kawin dalam berbagai instrument HAM di atas, menunjukkan bahwa setiap anak berhak atas pengakuan, jaminan, perlindungan dan perlakuan hukum yang adil serta mendapat kepastian hukum dan perlakuan yang sama di depan hukum. Keberlakuan Pasal 43 Undang-Undang Perkawinan tidak selaras dengan prinsip kewajiban negara berpartisipasi melalui undang-undang untuk menjamin pengakuan serta penghormatan atas hak-hak dasar warga negaranya. Negara/pemerintah seharusnya memberi jaminan hak-hak keperdataan anak luar nikah melalui peraturan perundang-undangan.

\section{Keadilan Bagi Anak Luar Kawin dalam Putusan Nomor 46/PUU-VIII/2010}

Secara fitrah, tidak ada perbedaan antara anak yang dilahirkan di dalam atau di luar perkawinan yang. Keduanya merupakan subjek hukum yang harus dilindungi hak-haknya oleh negara. Anak tidak bisa menerima sanksi atas perbuatan atau kesalahan yang dilakukan oleh orang tuanya. Islam mengajarkan bahwa setiap anak terlahir dalam kondisi yang suci, sebagaimana sabda Rasulullah SAW:

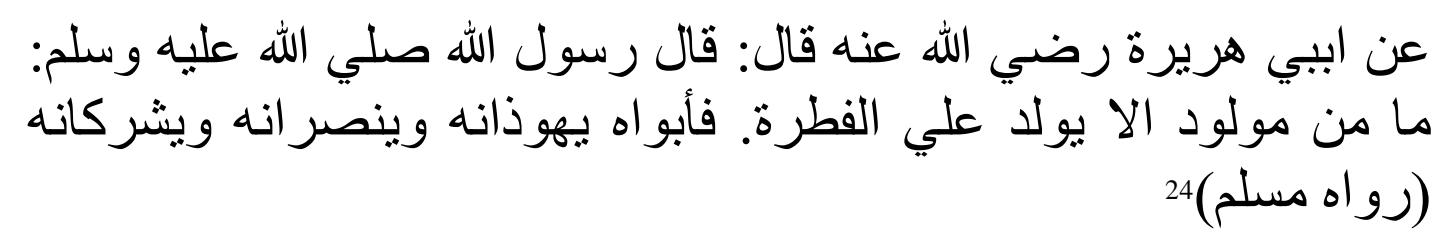

Artinya: Dari Abu Hurairah RA berkata bahwa rasulullah SAW bersabda: "tidaklah setiap anak itu lahir kecuali dalam keadaan suci. Orang tuanyalah yang akan menjadikannya yahudi, nashrani, atau musyrik" (HR. Muslim)

Meskipun demikian, di beberapa negara seperti Malaysia, Brunei Darussalam, Mesir termasuk Indonesia membedakan kedudukan dan hak keperdataan anak luar kawin. Anak yang terlahir di luar pekawinan yang sah hanya memiliki hubungan dengan ibu dan keluarga ibunya

\footnotetext{
${ }^{20}$ Maidin Gultom, Perlindungan Hukum Terhadap Anak dan Perempuan (Bandung: Refika Aditama, 2012 ), 103.

${ }^{21}$ Pasal 2 Undang-Undang No. 39 Tahun 1999 tentang Hak Asasi Manusia

22 Pasal 3 Undang-Undang No. 39 Tahun 1999 tentang Hak Asasi Manusia

${ }^{23}$ Undang-Undang Nomor 23 Tahun 2014 tentang Perubahan Atas Undang-Undang Nomor 23 Tahun 2002 tentang Perlindungan Anak

${ }^{24}$ Abu Husain Muslim bin Hajjaj Al Qusyairi Al Nisaburi, Shahih Muslim (Beirut: Daar Tayyibah, 2006), 641.
} 
saja sebagaimana diatur dalam Pasal 43 Undang-Undang Nomor 1 Tahun 1974 tentang Perkawinan. Konsekuensinya, anak tidak memiliki hak dari ayah biologis, baik berupa nafkah, biaya pendidikan, kesehatan, perwalian, dan kewarisan. ${ }^{25}$ Di dalam KUHPerdata anak luar nikah/kawin dibagi menjadi ada tiga macam, yaitu: (1) apabila orang tua salah satu atau keduanya masih terikat dengan perkawinan lain, kemudian mereka melakukan hubungan seksual dengan wanita atau pria lain yang mengakibatkan hamil dan melahirkan anak, maka anak tersebut dinamakan anak zina. ${ }^{26}$ (2) apabila orang tua anak diluar kawin itu masih sama sama bujang, mereka mengadakan hubungan seksual, dan hamil serta melahirkan anak, maka anak tersebut adalah anak di luar nikah (anak alami). ${ }^{27}$ (3) Selain itu juga dikenal istilah anak sumbang dalam KUHPerdata yaitu anak yang dilahirkan dari sebuah hubungan antara seorang laki-laki dan perempuan yang terlarang untuk melakukan perkawinan sebagaimana ditentukan dalam pasal 30 KUHPerdata karena memiliki hubungan darah. ${ }^{28}$ Dari ketiga pembagian tersebut, hanya anak luar nikah dalam kategori anak alami yang bisa mendapatkan hak-hak keperdataannya layaknya anak sah, hanya jika ada pengakuan dari orang tuanya terhadapnya. Sedangkan hal tersebut tidak berlaku bagi anak luar nikah dalam golongan anak zina dan sumbang. Tetapi anak zina dan anak sumbang dapat menuntut nafkah seperlunya tergantung pada kesanggupan orang tua biologisnya. ${ }^{29}$ Kondisi ini merupakan bentuk diskriminasi bagi anak-anak yang terlahir di luar perkawinan. ${ }^{30}$

Diskriminasi terhadap anak luar kawin, menurut Murtadla Muthahhari bertentangan dengan konsep keadilan bagi individu. Bagi Murtadla konsep adil dikenal dalam empat hal: pertama, adil bermakna keseimbangan dalam arti suatu masyarakat yang ingin tetap bertahan dan mapan, maka masyarakat tersebut harus berada dalam keadaaan seimbang, di mana segala sesuatu yang ada di dalamnya harus eksis dengan kadar semestinya dan bukan dengan kadar yang sama. Kedua, adil adalah persamaan dan penafian terhadap perbedaan apapun. Keadilan yang dimaksudkan adalah memelihara persamaan ketika hak memilikinya sama, sebab keadilan mewajibkan adanya persamaan. Ketiga, adil adalah memelihara hak-hak individu dan memberikan hak kepada setiap orang yang berhak mendapatkannya. Keadilan seperti ini adalah keadilan sosial dalam hidup di lingkungan masyarakat, dan dalam bernegara. Keempat, adil adalah memelihara hak atas berlanjutnya eksistensi. ${ }^{31}$ Madjid Khadduri menyatakan bahwa makna yang terkandung pada konsepsi keadilan Islam adalah menempatkan sesuatu pada tempatnya, membebankan sesuatu sesuai daya pikul seseorang, memberikan sesuatu menjadi hak seseorang dengan kadar yang semestinya. ${ }^{32}$ Hal ini tidak terlihat pada hak-hak keperdataan yang seharusnya diperoleh oleh anak luar nikah dari ayah biologisnya. Selain itu rasanya tidak adil bagi ibu anak tersebut jika harus sendirian memberikan penghidupan yang layak bagi si anak sedangkan si ayah tidak mempunyai kewajiban tersebut.

John Rawls juga menyatakan bahwa ada dua langkah penting yang harus diperhatikan demi terciptanya keadilan yang ia sebut fairness. Pertama, ditekankan pentingnya posisi asali. Posisi asali menjadi kondisi awal dimana rasionalitas, kebebasan (freedom) dan kesamaan hak

\footnotetext{
${ }^{25}$ M. Atho Mudzhar and Khoiruddin Nasution, Hukum Keluarga di Dunia Islam Modern: Studi Perbandingan dan Keberanjakan UU Modern dari Kitab-Kitab Fikih (Jakarta: Ciputat Press, 2003), 182.

${ }^{26}$ J. Andy Hartanto, Hukum Waris: Kedudukan dan Hak Waris Anak Luar Kawin Menurut "Burgerlijk Wetboek" Pasca Putusan Mahkamah Kontitusi (Yogyakarta: Laksbang Justitia, 2013), 30.

${ }^{27}$ Abul 'Ala Maududi, Kejamkah hukum Islam (Jakarta: Gema Insani Press, 1991), 81.

${ }^{28}$ Hartanto, Hukum Waris, 30.

${ }^{29}$ Hartanto, Hukum Waris, 31.

${ }^{30}$ Walaupun dari sudut pandang tertentu dianggap sudah dianggap mencerminkan keadilan. Seperti dalam hukum Islam serta UU Perkawinan menentukan bahwa anak luar nikah hanya mempunyai hubungan perdata dengan ibu dan keluarga ibunya. Hal tesebut sudah dianggap adil dengan alasan-tertentu walaupun dari segi lain dapat menimbulkan ketidakadilan bagi isteri dan anak tersebut.

${ }^{31}$ Murtadha Muthahhari, Keadilan Ilahi: Asas Pandangan-Dunia Islam (Jakarta: Mizan, 1995), 53-58.

${ }^{32}$ Madjid Khadduri, Teologi Keadilan, Perspektif Islam (Surabaya: Risalah Gusti, 1999), 119-201.
} 
(equality) merupakan prinsip-prinsip pokok yang dianut dan sekaligus menjadi sikap dasar dari semua pihak yang terkait dalam proses menciptakan keadilan. ${ }^{33} \mathrm{Hal}$ ini tidak sesuai jika dikaitkan dengan hak-hak keperdataan anak luar kawin yang didapatkan dari ayah biologisnya. Karena pada posisi asali, seharusnya anak luar nikah mempunyai hak yang sama layaknya anak sah lainnya dalam memperoleh hak-hak keperdataannya. Kedua, adanya konstitusi, undangundang, atau sistem aturan yang sesuai dengan prinsip keadilan. John Rawls percaya bahwa keadilan yang berbasiskan peraturan tetaplah penting karena pada dasarnya konstitusi atau undang-undang memberikan suatu jaminan hak-hak keperdataan anak luar nikah dari ayahnya. Hal tersebut tidak tercermin dalam pasal 43 ayat (1) UU Perkawinan. Anak hanya memiliki hubungan dengan ibu, sementara ayahnya bebas secara hukum dapat meninggalkan kewajibannya terhadap anak luar nikahnya tersebut. Gustav Radbruch menyatakan bahwa hukum adalah sebagai pengemban nilai keadilan, menurutnya nilai keadilan juga menjadi dasar dari hukum sebagai hukum. Nilai keadilan dalam hukum akan tercapai jika tidak ada kesamaan hak di depan hukum Nilai keadilan adalah materi yang harus menjadi isi aturan hukum. Sedangkan aturan hukum adalah bentuk yang harus melindungi nilai keadilan. Maka, jika dalam isi aturan hukum tidak memuat materi keadilan, maka nilai keadilan itupun tidak akan pernah tercapai.

Upaya perlindungan hak-hak anak luar nikah di Indonesia secara nyata terdapat pada putusan Mahkamah Konstitusi Nomor 46/PUU-VIII/2010 yang diputuskan pada Senin, 13 Februari 2012. Putusan ini terbit atas permohonan pengujian Undang-Undang yang diajukan oleh MM dan anaknya MIR. Pada prinsipnya MM memohon pengakuan hukum terhadap kedudukan MIR yang terlahir di luar nikah agar mempunyai kedudukan hukum yang sama dengan anak-anak sah pada umumnya, termasuk perlindungan terhadap hak-hak keperdataannya. Salah satu amar putusannya, majelis hakim Mahkamah Konstitusi menyatakan bahwa Pasal 43 ayat (1) UU Perkawinan "Anak yang dilahirkan di luar perkawinan hanya mempunyai hubungan perdata dengan ibunya dan keluarga ibunya", bertentangan dengan UUD'45 sepanjang dimaknai menghilangkan hubungan perdata dengan laki-laki yang dapat dibuktikan berdasarkan ilmu pengetahuan dan teknologi dan/atau alat bukti lain menurut hukum ternyata mempunyai hubungan darah sebagai ayahnya, sehingga ayat tersebut harus dibaca, " Anak yang dilahirkan di luar perkawinan mempunyai hubungan perdata dengan ibunya dan keluarga ibunya serta dengan laki-laki sebagai ayahnya yang dapat dibuktikan berdasarkan ilmu pengetahuan dan teknologi dan/atau alat bukti lain menurut hukum mempunyai hubungan darah, termasuk hubungan perdata dengan keluarga ayahnya".

Putusan tersebut memiliki konstribusi terhadap pembaharuan hukum perkawinan di Indonesia. Akibat hukum dari putusan ini adakah adanya hubungan keperdataan anak luar kawin dengan ayah biologisnya. Berlaku pula di antara keduanya hak dan kewajiban timbal balik termasuk pemberian hak-hak keperdataan anak oleh ayah biologisnya. ${ }^{34}$ Meskipun menimbulkan polemik, Putusan MK Nomor 46/PUU-VIII/2010 tersebut selaras dengan konsep keadilan yang ditawarkan Murtadlo Muthahhari. Terutama pada konsep keadilan yang ketiga yaitu adil adalah memelihara hak-hak indivudu dan memberikan hak kepada setiap orang yang berhak mendapatkannya. Karena dengan keluarnya putusan MK tersebut anak luar nikah dapat memperoleh hak keperdataan dari ayah biologisnya seperti nafkah, waris, hadlonah, hingga perwalian. Demikian juga dengan konsep keadilan yang dikemukakan Madjid Khadduri ${ }^{35}$

\footnotetext{
33 John Rawls, Teori Keadilan: Dasar-Dasar Filsafat Politik Untuk Mewujudkan Kesejahteraan Sosial Dalam Negara (Yogyakarta: Pustaka Pelajar, 2006), 13.

${ }^{34}$ Walaupun dari sudut pandang tertentu dianggap sudah dianggap mencerminkan keadilan. Seperti dalam hukum Islam serta UUPerkawinan menentukan bahwa anak luar nikah hanya mempunyai hubungan perdata dengan ibu dan keluarga ibunya. Hal tesebut sudah dianggap adil dengan alasan-tertentu walaupun dari segi lain dapat menimbulkan ketidakadilan bagi isteri dan anak tersebut.

${ }^{35}$ Khadduri, Teologi Keadilan, 119-201.
} 
dimana hak-hak keperdataan yang diperoleh oleh anak luar nikah dari ayah biologinya setelah Putusan Mahkamah Konstitusi Nomor 46/PUU-VIII/2010 dikeluarkan. Selain itu rasanya adil jika yang memberikan penghidupan yang layak bagi si anak tidak hanya bagi ibu anak tersebu sendirian saja melainkan si ayah mempunyai kewajiban tersebut juga.

Putusan ini selaras dengan pandangan John Rawls yang menyatakan bahwa persamaan hak dan kedudukan merupakan sarana menciptakan keadilan. ${ }^{36}$ Anak luar nikah berhak mendapatkan hak-hak keperdataan dari ayah biologisnya. Karena pada posisi asali, seharusnya anak luar nikah mempunyai hak yang sama layaknya anak sah lainnya dalam memperoleh hakhak keperdataannya. Selain itu, putusan ini merevisi Pasal 43 Undang-Undang Nomor 1 Tahun 1974 yang mendeskriminasikan anak luar kawin. Lahirnya putusan MK Nomor 46/PUUVIII/2010 diwarnai dengan kontroversi. Ada yang menerima karena itu demi kepentingan anak seperti Komnas HAM, Komnas Perlindungan Perempuan dan Anak. Selain itu ada yang menolak karena ditakutkan sebagai jalan melegalkan zina serta menyalahi syariat dengan menasabkan anak luar nikah kepada ayahnya. Bahkan MUI pusat mengeluarkan Fatwa Nomor: 11 Tahun 2012 Tentang Kedudukan Anak Hasil Zina dan Perlakuan Terhadapnya ${ }^{37}$. Dalam fatwa tidak mempunyai hubungan nasab, wali nikah, waris, dan nafaqah. Sedangkan hak-hak anak luar nikah yang wajib diberikan ayah biologisnya adalah biaya tumbuh kembang anak hingga dewasa selain itu anak luar nikah tidak berhak mendapatkan harta warisan dan hak kewalian dalam pernikahan (jika perempuan). Sebagai ganti ketiadaan hak waris, maka MUI memberikan kewajiban pada ayah untuk memberi wasiat wajibah ${ }^{38}$ bagi anak luar nikahnya.

Walapun pada dasarnya, dalam fatwa MUI tersebut (yang merupakan respon MUI terhadap putusan MK Nomor 46/PUU-VIII/2010 ) anak luar nikah (zina) tidak mendapatkan kewarisan, akan tetapi setidaknya melalui putusan ini seorang anak di luar nikah bisa mendapatkan wasiat wajibah. Dengan wasiat wajibah ini, setidaknya bisa menjadi sebuah solusi bagi ketiadaan hak mendapat warisan dari ayah biologis anak luar nikah tersebut. Jika dilihat dari kacamata keadilan, ada bagian-bagian yang diupayakan sama dengan anak sah, ketentuan tersebut setidaknya mengikis diskriminasi terhadap hak-hak anak yang lahir di luar pernikahan. Bagi penulis, putusan MK Nomor 46/PUU-VIII/2010 tersebut adalah pembatas antara wilayah kuratif dan wilayah preventif. Nasib Anak luar nikah yang terjadi sebelum putusan Mahkamah Konstitusi ini mencoba diberi perlindungan lebih dengan diberi penegasan tentang kebersambungan hak keperdataan anak luar nikah kepada ayah biologisnya sebagai upaya bagi pemerintah memberi sanksi bagi siapapun laki-laki yang membenihkan anak tersebut ke dalam rahim si ibu agar tidak dengan semena-mena meniggalkankan tanggung jawabnya sebagai ayah biologis terhadap anaknya. Karena dalam konsep agama apapun, istilah dosa turunan tidaklah dikenal.

Menurut Imam Musthofa, pembatalan keberlakuan Pasal 43 ayat (1) Undang-Undang No. Tahun 1974 tentang perkawinanbertujuan: 1) Memberi legalitas hukum hubungan darah antara anak dengan ayah biologisnya, yakni bahwa hubungan darah antara anak dengan ayah biologisnya yang semula hanya merupakan sebuah realitas menjadi hubungan hukum sehingga memiliki akibat hukum. 2) Memberi perlindungan hukum atas hak-hak dasar anak, baik terhadap ayahnya dan keluarga ayahnya maupun lingkungannya. 3) Memberi perlakuan yang adil terhadap setiap anak yang dilahirkan meskipun perkawinan orang tuanya tidak (belum) ada kepastian. 4) Menegaskan adanya hubungan perdata setiap anak dengan ayah biologisnya dan keluarga ayahnya menurut hukum sebagaimana hubungan perdata dengan ibunya dan keluarga ibunya. 5) Menegaskan adanya kewajiban ayah menurut hukum (legal custady) memelihara setiap anak yang dilahirkan dari darahnya. 6) Melindungi hak waris anak dari ayahnya karena adanya hubungan darah, hak dan tanggung jawab satu sama lain. 7) Menjamin masa

\footnotetext{
${ }^{36}$ Rawls, Teori Keadilan, 13.

37 Terlepas dari anak hasil pernikahan yang tidak dicatatkan (sirri). Menurut hukum Islam, anak hasil nikah sirri berhak hubungan perdata(nasab), wali nikah, waris, dan nafaqah.

${ }^{38}$ Wasiat wajibah adalah suatu wasiat yang diperuntukkan kepada ahli waris atau kerabat yang tidak memperoleh bagian harta warisan dar seorang yang wafat, karena adanya halangan syara'.
} 
depan anak sebagaimana anak-anak pada umumnya. 8) Menjamin hak-hak anak untuk mendapat pengasuhan, pemeliharaan, pendidikan dan biaya penghidupan, perindungan dan lain sebagainya dari ayahnya sebagaimana mestinya. 9) Memberi ketegasan hukum bahwa setiap laki-laki harus bertanggung jawab atas tindakannya dan akibat yang timbul karena perbuatannya itu, dalam hal ini menyebabkan lahirnya anak. Mereka tidak dapat melepaskan diri dari tanggung jawab tersebut. ${ }^{39}$

Setelah memberi solusi (atau setidaknya memberi kepastian hukum) kepada anak luar nikah yang lahir setelah keluarnya putusan MK Nomor 46/PUU-VIII/2010 tersebut (kuratif), maka MK berupaya dengan putusan MK tersebut untuk mencegah kasus-kasus yang sama untuk tidak terjadi lagi. Hal tersebut bukanlah upaya MK untuk melegalkan perzinaan. Melainkan sebaliknya merupakan upaya pencegahan MK agar tidak terjadi (atau dapat dikatakan menekan) kasus-kasus kelahiran seorang anak di luar pernikahan, selain itu untuk memberi sanksi atau dengan bahasa lunak adalah memberikan tanggung jawab bagi ayah biologis terhadap keberlangsungan anak (luar nikah)nya. Selain itu dengan putusan MK tersebut, seharusnya tidak melulu memperdebatkan hal-hal yang terjadi sebelum putusan MK ini diputuskan, tetapi bagaimana dari setiap elemen masyarakat dan pemerintah membangun moral bangsa yang kuat untuk mencegah hal-hal serupa terjadi terhadap generasi penerus bangsa Indonesia.

Tabel 1.

Tinjauan prinsip keadilan terhadap hak-hak keperdataan anak luar nikah sebelum dan setelah putusan MK Nomor 46/PUU-VIII/2010 dari ayah biologisnya

\begin{tabular}{|c|c|c|c|}
\hline No. & Sebelum & Setelah & Keterangan \\
\hline 1 & $\begin{array}{l}\text { Tidak berhak } \\
\text { mendapat nafkah } \\
\text { dari ayahnya. }\end{array}$ & $\begin{array}{l}\text { Berhak mendapat } \\
\text { nafkah dari } \\
\text { ayahnya. }\end{array}$ & \multirow{4}{*}{$\begin{array}{l}\text { Sesuai dengan prinsip } \\
\text { keadilan milik Murtadla } \\
\text { Muthahari dan Madjid } \\
\text { Khadduri. Juga konsep } \\
\text { keadilan barat yang terdiri } \\
\text { dari justice as farness- nya } \\
\text { John Rawls dan konsep } \\
\text { keadilan kamutatifnya } \\
\text { Aristoteles juga nilai } \\
\text { keadilannya Gustav } \\
\text { Radbruch. Begitu juga } \\
\text { dengan prinsip keadilan } \\
\text { dalam Hak Asasi Manusia. }\end{array}$} \\
\hline 2 & $\begin{array}{l}\text { Tidak berhak } \\
\text { mendapat } \\
\text { hadlonah } \\
\text { (pendidikan dan } \\
\text { pemeliharaan) } \\
\text { dari ayahnya. }\end{array}$ & $\begin{array}{l}\text { Berhak mendapat } \\
\text { hadlonah } \\
\text { (pendidikan dan } \\
\text { pemeliharaan) dari } \\
\text { ayahnya. }\end{array}$ & \\
\hline 3 & $\begin{array}{l}\text { Tidak berhak } \\
\text { mendapat } \\
\text { perwalian dalam } \\
\text { pernikahan dari } \\
\text { ayahnya jika anak } \\
\text { tersebut } \\
\text { perempuan }\end{array}$ & $\begin{array}{l}\text { Berhak mendapat } \\
\text { perwalian dalam } \\
\text { pernikahan dari } \\
\text { ayahnya jika anak } \\
\text { tersebut perempuan. } \\
\text { (Sedangkan menurut } \\
\text { MUI, walinya adalah } \\
\text { Wali Hakim) }\end{array}$ & \\
\hline 4 & $\begin{array}{l}\text { Tidak berhak } \\
\text { mendapat warisan } \\
\text { dari ayahnya. }\end{array}$ & $\begin{array}{l}\text { Berhak mendapat } \\
\text { warisan dari } \\
\text { ayahnya. } \\
\text { (Sedangkan menurut } \\
\text { MUI, berhak } \\
\text { mendapat Wasiat } \\
\text { Wajibah) }\end{array}$ & \\
\hline
\end{tabular}

${ }^{39}$ Imam Mustofa, "Dampak Putusan Mahkamah Konstitusi Mengenai Pasal 43 Ayat (1) Undang-Undang Perkawinan No 1 Tahun 1974 Terhadap Hukum Keluarga Di Indonesia," Al-Manahij: Jurnal Kajian Hukum Islam 6, no. 2 (Juli 2012): 291. 


\section{Kesimpulan}

Anak luar nikah mendapatkan berbagai perlakukan diskriminatif sebelum munculnya Putusan Mahkamah Konstitusi Nomor 46/PUU-VIII/2010. Berlakunya Pasal 43 ayat (1) Undang-Undang Nomor 1 Tahun 1974 tentang Perkawinan menyebabkan anak luar nikah tidak berhak mendapatkan hak-hak keperdataan seperti memperoleh nafkah, pendidikan, pemeliharaan, perwalian dalam perkawinan jika anak tersebut perempuan, dan tidak berhak mendapat saling mewarisi dengan ayah biologisnya jika telah meninggal. Stigma negatif juga diberikan kepada anak luar kawin, sehingga dapat mempengaruhi perkembangan psikologisnya. Kondisi ini tidak sesuai dengan prinsip keadilan dan Hak Asasi Manusia. Dua prinsip di atas menghendaki bahwa segala bentuk diskriminasi terhadap anak atas alasan apapun harus dihapus karena pada prinsipnya setiap anak yang dilahirkan dalam keadaan suci dan tidak sedang menanggung dosa yang telah dilakukan orang tuanya. Dari berbagai konsep kaadilan di atas, menuntut adanya perlakuan yang sama terhadap anak yang lahir di luar pernikahan layaknya anak sah pada umumnya.

Putusan Mahkamah Konstitusi Nomor 46/PUU-VIII/2010 menyatakan bahwa Pasal 43 ayat (1) Undang-Undang Nomor 1 Tahun 1974 tentang Perkawinan bertentangan dengan UUD 1945 sepanjang dimaknai menghilangkan hubungan perdata dengan laki-laki yang dapat dibuktikan berdasarkan ilmu pengetahuan dan teknologi dan/atau alat bukti lain menurut hukum ternyata mempunyai hubungan darah sebagai ayahnya. Putusan ini memberikan payung hukum kepada anak-anak yang terlahir di luar perkawinan untuk memperoleh hak-hak keperdataan dari ayah biologisnya serta keluarga ayahnya. Putusan ini sesuai dengan prinsip keadilan dan Hak Asasi Manusia yang menekankan kesetaraan, non-diskriminasi, dan kewajiban negara untuk melindungi hak-hak warga negaranya. Meskipun demikian, putusan ini masih multi tafsir sehingga memerlukan peraturan perundang-undangan yang memperkuat dan mengakomodir hak-hak keperdataan anak luar nikah oleh Pemerintah.

\section{Daftar Pustaka}

Abul 'Ala Maududi. Kejamkah hukum Islam. Jakarta: Gema Insani Press, 1991.

Alam, Andi Syamsu, and M Fauzan. Hukum pengangkatan anak perspektif Islam. Rawamangun, Jakarta, Indonesia: Kencana Prenada Media Group, 2008.

Ariyanto. Mahfud MD, Hakim Mbeling. Jakarta: Konstitusi Press, 2013.

Ashshofa, Burhan. Metode Penelitian Hukum. Jakarta: Rineka Cipta, 2001.

Devita, Irma. "Pengertian Anak Luar Kawin Dalam Putusan MK." Accessed October 28, 2014. http://irmadevita.com/2013/pengertian-anak-luar-kawin-dalam-putusan-mk/.

Djamil, Nasir. Anak Bukan untuk Dihukum: Catatan Pembahasan UU Sistem Peradilan Anak. Jakarta: Sinar Grafika, 2013.

Gultom, Maidin. Perlindungan Hukum Terhadap Anak dan Perempuan. Bandung: Refika Aditama, 2012.

Hartanto, J. Andy. Hukum Waris: Kedudukan dan Hak Waris Anak Luar Kawin Menurut "Burgerlijk Wetboek” Pasca Putusan Mahkamah Kontitusi. Yogyakarta: Laksbang Justitia, 2013.

Ibrahim, Johnny. Teori Dan Metode Penelitian Hukum Normatif. Malang: Bayu Media Publishing, 2006.

Khadduri, Madjid. Teologi Keadilan, Perspektif Islam. Surabaya: Risalah Gusti, 1999.

Marzuki, Peter Mahmud. Penelitian Hukum. Jakarta: Kencana, 2010.

Mudzhar, M. Atho, and Khoiruddin Nasution. Hukum Keluarga di Dunia Islam Modern: Studi Perbandingan dan Keberanjakan UU Modern dari Kitab-Kitab Fikih. Jakarta: Ciputat Press, 2003.

Mustofa, Imam. "Dampak Putusan Mahkamah Konstitusi Mengenai Pasal 43 Ayat (1) UndangUndang Perkawinan No 1 Tahun 1974 Terhadap Hukum Keluarga Di Indonesia." Al-Manahij: Jurnal Kajian Hukum Islam 6, No. 2 (Juli 2012).

Muthahhari, Murtadha. Keadilan Ilahi: Asas Pandangan-Dunia Islam. Bandung: Mizan, 1995. 
“Putusan MK Tak Bermanfaat Untuk Anak Luar Kawin.” Accessed November 29, 2012. http://www.hukumonline.com/berita/baca/lt4f7475cd1eb4d/putusan-mk-tak-bermanfaatuntuk-anak-luar-kawin.

Ramulyo, M. Idris. Perbandingan Pelaksanaan Hukum Kewarisan Islam dengan Kewarisan Menurut Hukum Perdata (BW). Jakarta: Sinar Grafika, 1994.

Rawls, John. Teori Keadilan: Dasar-Dasar Filsafat Politik Untuk Mewujudkan Kesejahteraan Sosial Dalam Negara. Yogyakarta: Pustaka Pelajar, 2006.

Satrio, J. Hukum keluarga tentang kedudukan anak dalam undang-undang. Bandung: Citra Aditya Bakti, 2000.

Soekanto, Soerjono, and Sri Mamudji. Penelitian Hukum Normatif: Suatu Tinjauan Singkat. Jakarta: RajaGrafindo Persada, 2006.

Thaib, H. M. Hasballah, and Iman Jauhari. Kapita Selekta Hukum Islam. Medan: Pustaka Bangsa Press, 2004.

Undang-Undang Nomor 1 Tahun 1974 tentang Perkawinan

Undang-Undang Nomor 23 Tahun 2014 tentang Perubahan Atas Undang-Undang Nomor 23

Tahun 2002 tentang Perlindungan Anak 